\title{
Niche Marketing And Tourism
}

\section{Ayşe Nevin SERT}

Selçuk University, Konya, Turkey.

nevinsert@gmail.com

\begin{abstract}
Tourism is an important sector contributing to the development of the country's economy. In order to get more share from this competitive sector, more profitable new tourism markets should be established and appropriate marketing strategies should be developed. In this study, the term of niche marketing and the determination of niche market are examined. The relationship between niche marketing and other marketing methods is mentioned and its advantages and disadvantages are stated. In addition, the applications of niche market in the tourism industry has been indicated and the reasons for increasing practice of niche marketing as a strategy by marketers are being identified. This paper is intended to present a concise status of niche marketing and thereby provide a basis for marketers and research persons.
\end{abstract}

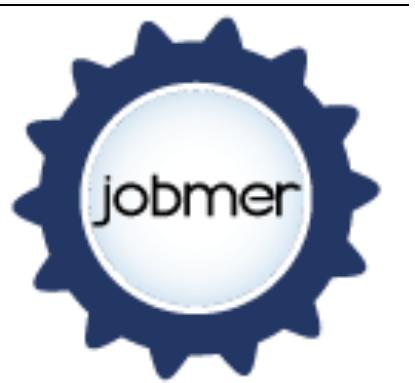

Journal of Business Management and Economic Research Vol.1, Issue.1, 2017 pp.14e 25

Doi: 10.29226/jobmer.2017.1

Keywords: Niche marketing, niche marketing strategy, niche tourism, special interest tourism.

\section{Suggested Citation:}

Sert, A. N., (2017) Niche Marketing And Tourism, Journal of Business Management and Economic Research, Vol.1, Issue.1, pp.14-25 


\section{INTRODUCTION}

With the 20th century, rapid changes took place throughout the world in social, cultural and economic life. People's needs and desires have increased with the rising prosperity. Consumers want to satisfy their demands and needs at the highest level with increasing welfare. All these changes and technological developments have brought many innovations to production and marketing methods. In order to meet the wishes and needs of the consumers in the best way, it is aimed to develop special products and services and present them to customers. All these changes and technological developments have brought many innovations to production and marketing methods. As order to meet the wishes and needs of the customers in the best way, it is aimed to develop special products and services and present to them (Choudhary, 2014). Therefore, requirements of our time and the changing of the customers' priorities have put the niche marketing on the agenda of companies. It could be argued that with the increase of competition in the global world, middle and small businesses are more likely to be in niche markets due to their weak position against the big businesses. Small and medium-sized enterprises have gone to great lengths to protect themselves by trying to obtain niche markets that do not attract the attention of large businesses. Niche market is a small market consisting of an individual customer or a small group of customers with similar characteristics or needs. The definition of niche marketing is that positioning into small, profitable homogeneous market segments which ignored or neglected by others (Dalgic and Leeuw, 1994).

Mass goods and services seem to be inadequate to meet the wants and needs of the consumers shaped in this age. The necessity of developing and marketing special goods and services in order to satisfy the changing demands and needs of consumers has increased the importance of niche marketing. This paper is significant as it could enlighten related companies in tourism industry about the niche marketing techniques. In addition, it is also notable as it might guide researchers who intend to study on a relevant subject.

\section{Niche Marketing Framework}

Before the industrial revolution, production and marketing were carried out in accordance with the specific wants and needs of customers in small, remote and scattered niche markets. Along with the industrial revolution, mass production and marketing came out. But since World War II, the process has been reversed, especially the major American and European markets have begun to divide into small markets. In this segmentation, single-parent households, families with double income and no children, working women, technological advances, changing demographic characteristics and lifestyles, increasing spare time, the decline in brand loyalty, confronting with too many products, services, stores and spreading the promotional activities over large area, have been effective (Dalgic and Leeuw, 1994). Changing in customer preferences and wants/needs have created diverse markets, in contrast to the traditional mass market. Looking at the evolutionary process of niche marketing, it is seen that it emerged before the industrial revolution and although it was in the shadow of mass marketization, it was continued to be applied for a while and for the last 20 years it has been seen a very important (Yapraklı, 2004).

It is becoming increasingly difficult to maintain continuity in today's market where competition and the number of competitors entering the market is increasing day by day. In the eradicate competition conditions imposed by globalization, the reshaping of marketing policies is gaining importance (Soyuer, 2004). The changing needs of enterprises and organizational markets, increasing competition and structural changes, developments in production and information technologies, increasing diversification in consumer tastes and habits challenge the companies and consequently reducing the validity of traditional strategies (Dalgic, 2002). The increased diversity of markets and advanced technologies 
enabling new marketing approaches and the deterioration of large companies and their traditional marketing approaches (Dalgic and Leeuw, 1994). In this circumstances, especially small and medium-sized enterprises have been turning to niche marketing in order to survive in a highly competitive environment and to maximize their marketing advantages (Demir and Şahin, 2000). Small businesses view niche marketing as an important way out of the competition of big businesses in protecting their assets, maintaining their profitability, having the potential to grow, and creating consumer dependence (Dalgic and Leeuw, 1994). Various definitions of niche marketing have been made. Kotler (2003) defined niche marketing as the process of addressing an unsatisfied small market segment. Another definition of niche marketing is identifying consumers' special wishes and then creating a product, action, situation or opportunity that fits their personality and wants (Brey, 1991; Allen etc., 2012). According to Dalgic and Leeuw (1994), niche is a small market consisting of a small number of customer groups with similar characteristic needs and they describe the niche market as a small market consisting of a small number of customer groups with similar characteristic needs. One of the most comprehensive definitions of niche marketing belongs to Collins. According to Collins (1994), niche marketing is a marketing technique that has made it compulsory to re-organize its goods and services in accordance with the customers, thus offer the best opportunity to come from above the competition. Therefore, it enables the companies to provide total customer satisfaction by fulfilling their special wants and needs and actualizing the quality revolution. Although the niche market is defined as a small market in real terms, it can sometimes be made up of millions of individuals. It is said that the number of citizens with disabilities in Turkey is around 8 million, and a product that deals with all the disability will be both a niche and a mass market. And although niche markets in general are really small markets, big markets often originate from niche markets (Dalgic, 2002). In niche marketing, instead of producing goods / services that everyone likes, it is about the production of goods / services that few people love very much (Noy, 2010). Moving from common points of definitions, niche marketing can be defined as a process of offering the products that are differentiated and do not have many alternatives to an individual customer or a narrowly defined group of customers with similar characteristics or needs (Albayrak, 2006; Friedman, Lopez-Pumarejo and Weiser Friedman, 2007) and the main features can be summarised as follow (Kotler, 2003):

- The customers in the niche have a distinct set of needs.

- They are willing to pay a premium to the firm that best satisfies their needs.

- The niche is not likely to attract other competitors.

- The nicher gains certain economies through specialization.

- The niche has size, profit, and growth potential.

There are different approaches to niche marketing and these approaches in the literature can be classified under three groups. The first group is the "push marketing" approach. This approach takes the "market segmentation" one step further by creating a distinct group of customers (Kara and Kaynak, 1997). The second approach is the "pull marketing" approach. Similarly, to the first group, it is closely related to the market segmentation. However, more attention is paid to the customer's point of view here. Niche marketing is simply defined as a form of concentrated marketing (Shani and Chalasani, 1992; Weinstein, 1994; Parrish, Cassill, Oxenham and Jones, 2005). Shani and Chalasani (1992) separated niche marketing from market segmentation. According to them market segmentation is characterized by the "topdown" approach, which breaking a large market into smaller and more manageable submarkets. On the other side niche marketing is characterized by "bottom up" approach which marketer begin from meeting the wants and needs of a few customers and gradually 


\section{Journal of Business Management and Economic Research}

builds up a lager customer base. In the third approach, both "push marketing" and "pull marketing" approaches are accepted. According to this approach, the niche market is to divide a market segment into subgroups or into smaller customer groups. The niche market divides the traditional market into smaller sub-markets and applies different marketing programs to each small sub-market segment or niches. The successes of the niches in these sub-markets are related to specializations and differentiations (Linneman and Stanton, 1991; Kotler, 2003).

\section{Identifying a Niche Market}

In order to determine the niche market, firstly, the existing market needs to be well known and then it should be analysed whether this market will be divided into smaller niche markets. Therefore, some features that determine niche market are listed below (Dalgic and Leeuw, 1994):

- It should have sufficient size and profitability.

- There should be growth potential.

- Customers with purchasing power.

- A different approach should be needed.

- There must be competitive advantage for the new entrants companies.

- The market must not be noticed by other businesses.

However, to determine the potential niche market, the customers who are one of the most important power of the companies, needs to be well analysed. Therefore, the companies need to know the answers to the questions below (Linneman and Stanton, 1991; Parrish etc., 2005):

- Who are your heavy and light users?

- Which customers are expanding their purchases?

- Where are your customers located?

- Which customers can you most profitably serve?

- What do your customers really value?

- Do your customers purchase your product with the same frequency?

- What promotion best appeals to your various customers?

- Who makes the purchasing decisions?

- Do all your customers buy your whole line of products and services?

According to Dalgic and Leeuw, (1994), beside the determine the target customers some points must be taken into account when deciding on the niche market and achieving success. Some of them are listed below:

- Companies should know themselves. They should analyse their own structures and determine their strengths and weaknesses, their uniqueness, competitive advantages, distinctive competences, regional and traditional characteristics.

- Companies should know their customers well. They should offer them a high value added product.

- Companies should know their competitors. The definition of competitors is important in terms of creating differences and preventing possible attacks. 
- Companies should develop a continuous information system. Present-day database techniques can provide comparatively cheap, efficient marketing tool. This database can register prospects and customer traits. Due to the fact that in niche marketing the decisions based on profit and not on sales volume, which is of secondary importance, the profit figures are needed. Also customer databases need to be linked to other marketing information systems and business intelligence systems in order to be responsive to the marketplace.

- Companies should apply differentiation. They should offer significant benefits to their customers, determine what customers real values are and appeal to these values better than anyone else. The position should taken by differentiation and segmentation. The position is better taken on their own strengths and the weaknesses of others. Also developing a clear product image for each niche is very important.

- Companies should not compete in the same market segments with themselves and avoid competing with their own products in the same market segments.

- Companies should cover all the bases to deter potential competitors. To do this, they create high entry barriers through building a close relationship with their customers, patents, copyrights, alliances and relationship marketing.

- Companies should stay flexible and make sure that you do not exceed their limit by expanding all their abilities and resources.

- Companies should develop a corporate marketing strategy as they cannot develop their niche markets as stand-alone markets.

- Companies should be alert and be in control as it is essential to watch constantly for shifts in the marketplace and take the necessary measurements.

- Companies should not be static but look for new pastures continuously and consider conglomerate diversification (be careful, watch your resources). They should also look at emerging markets.

- Companies should minimize their dependence on any one customer or product and try to increase alternatives.

\section{The Steps to Implement Niche Marketing}

The steps to implement niche marketing are basically as follows (İslamoğlu, 1999: 272).

- Besides existing customer base and market, a market segment / segments is chosen by investigated the opportunities of the current market.

- Emerging markets and their trends are explored.

- Developments in publications related to the serving market niche are constantly monitored.

- The prospective customers who buy, show interest in, or tend to buy products and/or services of the companies should be detected with market researches.

- Existing and potential customers are grouped by taking into account their certain behaviour patterns.

- If there is another niche that is not targeted at the market, production or service can be tailored or modified to meet its needs.

- Marketing mix and promotional activities are planned and implemented. 


\section{Advantages and Disadvantages of Niche Marketing}

In the literature, both the advantages and disadvantages of niche marketing have been mentioned, but mostly their advantages are stated. Some them are given below.

\section{Advantages:}

The fastest growth method for companies is niche marketing. Niche marketing provide the companies the high competition, high profit margins and strong market position (Byers, 1991). It is claimed that niche marketing provides the best opportunity to companies for overcoming the competition, making quality revolution and providing total consumer satisfaction (Collins, 1994). According to Parrish (2003) in niche marketing, as the companies have a small customer base, they have a chance to get to know them very well and satisfy their wants and needs properly. In return customer satisfaction and loyalty are established. Another advantage is that the market segment can be identifiable exactly and the customers are fit for one or more of the company's expertise areas (Noy, 2010). Besides, there is no need for a lot of funding to attract the attention of customers who are interested in the niche market's goods and services (Özcan, 1997).

Dalgic and Leeuw (1994) point out that companies can compete with their competitors by turning to niche markets and thus have a better chance of survival. Niche marketing also ensure expertise on a subject and also give the opportunity to transfer this expertise to other products, areas and niche markets. Kotler (2003) claims that niche marketing is profitable as the companies knows the business and their customers' needs so well they take the better position to meet their need; thus they can charge a substantial mark up over costs due to the added value, and earn higher accordingly. Besides the profitability another advantage offered by niche marketing is easy defence against potential competitors (Parrish vd., 2005). The customers targeted by niche market can be reached through easily identifiable distribution channels (media, commercial publications, unions, conferences, etc.) (Özcan, 1997). Niche marketing makes the marketing activities easier. Companies that focus on a specific industry or a certain geographical area can develop more effective marketing strategies. Instead of producing goods and services that will satisfy a wide range of customers and reaching them with a wide distribution network, it can be heavily focused on a small market segment with narrow marketing strategies and fewer resources (Demir and Şahin, 2000).

\section{Disadvantages:}

Despite its many advantages, niche marketing includes some risks. The first risk is that the competitors will attack to get a share of the profitable market. The niche market does not make profit forever. Even if it is protected by patents or laws, a profitable niche will always attract competition, and when competition is on the rise, the companies will have difficulties to differentiate themselves from other companies (Brodsky, 2004). The second risk is cannibalization. When a company introduces a new product to the market, one of its own established markets is "eaten away" by it. This is called "cannibalization" (Parrish etc., 2005). The third risk is that changing of the preferences of the customers. When this preferences change the niche markets wear down easily as it may probably be not tolerated this sudden changes (Shani and Chalasani, 1992). 


\section{Relation of Niche Marketing to Other Marketing Methods (A Comparison of Niche Marketing and Mass Marketing)}

Niche marketing has evolved as an alternative marketing method to mass marketing (Kotler, 2003). While some researches highlight niche marketing, others highlight mass marketing.

Table 1. Mass Marketing vs. Niche Marketing

\begin{tabular}{l|l|l|}
\hline Market & Mass Marketing & Niche Marketing \\
\hline Product & Large market & Small market \\
\hline Customer & Feneric or broad product & Focused or specialized product \\
\hline Organization & Central and bureaucratic & Coyal customers \\
\hline Target & All market & $\begin{array}{l}\text { A small group that have not been } \\
\text { met their needs }\end{array}$ \\
\hline Competition & Intense competition & $\begin{array}{l}\text { No competition or weak } \\
\text { competition }\end{array}$ \\
\hline Marketing & Product focused & Modern marketing approach \\
\hline Production / & High production quantity & High profit margin \\
\hline Profitability & &
\end{tabular}

Source: Parrish, 2003: 26; Albayrak, 2006:223.

As in table 1, mass market is characterized as a big market, no brand, general product and customers with low loyalty. In niche market, there are small markets, customized products and loyal customers. There is intense competition in mass marketing and there is little competition in niche marketing. There is high volume production in mass market but high profit margins in niche marketing.

When looking at the product life cycle shown below in figure 1, an interesting picture emerges. In the introduction stage (entry stage) the product is the niche. At times, this niche product becomes a mass market. When the product reaches maturity the market becomes saturated, innovation occurs and eventually the mass market tends to turn niche markets (Parrish, 2003; Allen, Parrish, Cassill and Oxenham, 2012). In niche marketing, instead of producing goods and services that everyone likes, the goods and services are produced that few people like very much. In mass markets, a single product is made for the whole market and many people are satisfied a little (Kotler, 2003). 


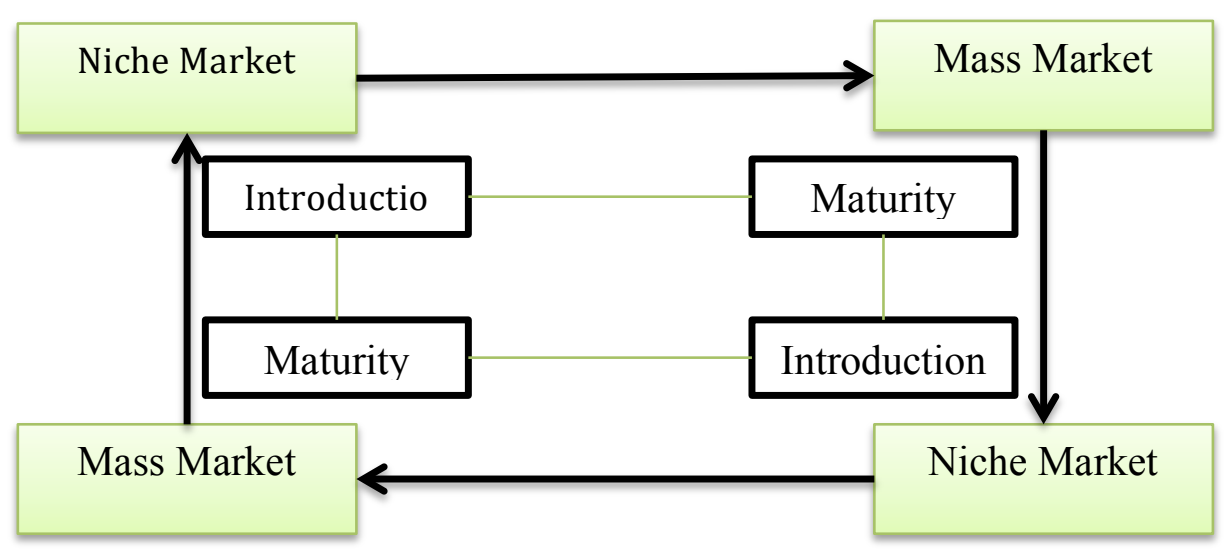

Figure 1: Evolution Cycle of Niche Markets and Mass Markets (Parrish, 2003:27).

Although market segmentation and niche marketing consider analogous and even interchangeable, they are actually different. Market segmentation is done from top to bottom. A big market divides in to smaller and easily managed segments. It is called a top-down approach. On the other hand, niche marketing is a bottom-up approach where the marketer starts from the needs of a few customers and gradually builds up a larger customer base. This is in contrast to breaking up a market into smaller markets. In this respect niche marketing may be termed as inverted or reversed segmentation (Dalgic and Leeuw 1994).

Table 2. Market Segmentation vs. Niche Marketing

\begin{tabular}{|l|l|}
\hline Market Segmentation & Niche Marketing \\
\hline Top-down approach & Bottom-up approach \\
\hline The outpoint is differences & The outpoint is similarity \\
\hline All slice elements are considered similar & Even a single customer can be a goal \\
\hline Relatively large & Relatively small \\
\hline The output point is an existing product & The output point is unmet wants and needs \\
\hline Focus on a so-called homogeneous group & Focuses on individuals or small group \\
\hline The objective is to manageable small group & The objective is to meet special needs \\
\hline
\end{tabular}

Source: Albayrak, 2006:223

As shown in Table 2, niche marketing benefits from relational marketing and database marketing. To achieve success in niche marketing, it is necessary to develop long-lasting and strong relationships between companies and customers and thus to provide customer loyalty (Dalgic and Leeuw, 1994). Relationship marketing establish, maintenance and enrichment the relationship with customers and other business partners for ensuring the companies achieving their objectives. The companies should also take advantage of database marketing to implement relationship marketing.

Database marketing is a strategy that describes how to communicate with, act on, and maintain current and prospective customers using customer databases and other databases (products, suppliers, resellers). With using the relationship marketing and database marketing in a harmonious, the protective walls against competitors, that is the most important advantages of niche marketing, could be set up (Albayrak, 2006). 


\section{Niche Marketing in Tourism Sector}

As a growing segment of the industry, niche tourism has recently begun to gain importance in the modern tourism sector which has high competitiveness. Instead of trying to cater to the needs of all guests, the niche tourism has a sophisticated process to distinguish and differentiate tourists. The tourists interested in niche tourism can be described as a tourists who have very specific individual interests, needs, desires and priorities and try to achieve them with the experience or activity they will experience in a particular destination (Novelli, 2005).

While many companies operating in classical tourism have difficulties in finding customers in intense competition environment; the companies that organize tours for special interest tourism can find customers easily. For small businesses to survive in the sector; it is becoming compulsory to prepare travel programs targeting special interests, and to specialize in congress and meeting etc. tourism and to appeal to customers who are inclined to create their own vacation by staying outside mass tourism (Küçükaslan, 2009). Tourism managers and planners who see tourism as a dynamic tool in terms of economic development, consider the niche marketing as a means to attract the tourists who are more profitable, less harmful and most importantly long staying (Novelli, 2005). For example, Marriott used to be an upscale hotel chain. Today, besides the Marriott Hotels (the company's major business), there are Marriott Suites, Residence Inns by Marriott, Courtyards by Marriott, and Fairfield Inns - each serving a smaller, targeted segment of the market and competing with niche firms like Noble House Hotels on one end and small luxury hotels on the other (Noy, 2010).

It is estimated that in the tourism industry where intense competition is experienced due to globalization, big businesses will grow bigger, medium-sized businesses will disappear and small businesses can survive only in niche markets. Therefore, in today's competitive environment, doing things that are not done and entering the markets (eg. underwater tourism, ecotourism types, etc.) that have not yet been entered but have certain potentials, enables small businesses to survive (Tekeli, 2001). The types of tourism that niche marketing can be applied to are very diverse. The types of special interest tourism are suitable for niche marketing. For example, farm tourism, bird watching, dark tourism, hunting tourism, adventure tourism etc.

Table 3. Classification of Special Interest Tourism Types

\begin{tabular}{|c|c|c|c|}
\hline $\begin{array}{l}\text { Types Based on } \\
\text { Nature }\end{array}$ & $\begin{array}{l}\text { Types Based on } \\
\text { Culture }\end{array}$ & $\begin{array}{l}\text { Types Based on } \\
\text { Education }\end{array}$ & $\begin{array}{l}\text { Types Based on a } \\
\text { Hobbies }\end{array}$ \\
\hline $\begin{array}{l}\text { - Botanical Tourism } \\
\text { - Farm Tourism } \\
\text { - Mountain Tourism } \\
\text { - Nature Tourism } \\
\text { - Air Sports Tourism } \\
\text { - Winter / Ski Tourism } \\
\text { - Village Tourism } \\
\text { - Bird Watching } \\
\text { - Water sports Tourism } \\
\text { - Agricultural Tourism } \\
\text { - Highland Tourism }\end{array}$ & $\begin{array}{l}\text { - Dark Tourism } \\
\text { - Ethnic Tourism } \\
\text { - Festival Tourist } \\
\text { - Silk Road Tourism } \\
\text { - Faith Tourism } \\
\text { - Cultural Tourism } \\
\text { - Third Age } \\
\text { Tourism } \\
\text { - Cultural Heritage } \\
\text { Tourism }\end{array}$ & $\begin{array}{l}\text { - Educational } \\
\text { Tourism } \\
\text { - Youth Tourism } \\
\text { - Congress tourism }\end{array}$ & $\begin{array}{l}\text { - Shopping Tourism } \\
\text { - Hunting Tourism } \\
\text { - Golf Tourism } \\
\text { - Gambling Tourism } \\
\text { - Adventure Tourism } \\
\text { - Cave Tourism } \\
\text { - Rafting Tourism } \\
\text { - Wine Tourism } \\
\text { - Yacht Tourism }\end{array}$ \\
\hline
\end{tabular}

Source: Kozak and Bahçe, 2006:137. 


\section{Journal of Business Management and Economic Research}

As shown in table 3, there are types of niche tourism for tourists who demand more specific products and services other than mass tourism that is defined as sea-sand-sun can offer. Some of these tourism types require less investment and financial resources. Village tourism and agricultural tourism are some of them.

\section{CONCLUSIONS}

At the present time, globalizing has changed the rules and techniques of the traditional marketing that is not sufficient enough any longer. As the customers prosperity have increased, they try to satisfy their wants and needs at the highest level, but the mass products are inadequate to meet this demand. Today's consumer with individualistic approach will demand individualized products and services because of intending to differentiate himself.

This is the case within the tourism industry. Studies to investigate changes in the expectations, wants and needs of tourists reveal that tourists now prefer different types of tourism activities instead of just sea, sand and sun. Therefore, countries should plan and develop tourism types that will meet differentiated and high-level expectations, desires and preferences in order to increase share in the tourism market.

Tourists are the most important part of marketing planning. The number of tourists is so high, the countries where they come are so diverse and their needs and buying habits are so different that companies do not have the opportunity to satisfy all tourists. For this reason, every company is confronted with the obligation to identify areas where they can serve in the best and most efficient way. Moreover, it is unimaginable that a particular tourism product has all the qualities that are appropriate to the expectation and needs of all the tourists. Therefore, instead of spending marketing efforts for trying to please all tourists, it would be right to identify those that are particularly important for companies, and to direct marketing efforts solely on the needs and desires of this particular segment. Tourism marketers would be better think small rather than big. Smaller market shares, small advertising budgets, but premium prices. In accordance with the niche marketing principle, producing and marketing goods and services that few people like very much, instead of goods / services that everyone likes a little, will contribute to grow the tourism industry. 


\section{REFERENCES}

Albayrak, T. (2006). Niş Pazarlama Prensipleri ve Ortopedik Destek Ürünleri Pazar Örneği. Akdeniz İ.I.B.F. Dergisi (11), 219-235.

Allen, R., Parrish,, E., Cassill, N., \& Oxenham, W. (2012). Assessing the validity of a niche strategy model in predicting the potential and success of niche markets and products. The Journal of The Textile Institute. 103(8), 900-911.

Brodsky, N. (2004). The Myths About Niches, Street Smarts by Norm Brodsky. Inc. Magazine. https://www.inc.com/magazine/20040801/nbrodsky.html?cid=search (22.04.2017).

Choudhary, S. (2014). Rooting by Niche Marketing. International Journal of Advanced Research in Management and Social Sciences. 3(10), 84-91.

Collins, M. (1994). Common-Sense Niche Marketing. Small Business Reports. 20 (9)

Dalgıç, T. (2002). Niş Pazarlamanın İlkeleri: Gerillalar Gorillere Karşı. Pazarlama ve İletişim Dergisi, 1(1), 30-36.

Dalgıç, T. \& Leeuw, M. (1994). Niche Marketing Revisited: Concept Applications and Some European Cases. European Journal of Marketing, 28(4), 39-55.

Demir, M. \& Şahin, A.H. (2000). Küçük ve Orta Büyüklükteki İşletmelerin (KOBİ) Pazarlama Problemleri İçin Bir Çözüm Önerisi: Niş Pazarlama. Pazarlama Dünyası, 14 (2000-05).

Friedman, H.H, Lopez-Pumarejo, T., \& Weiser Friedman, L. (2007) A New Kind of Marketing: Creating Micro-Niches Using Resonance Marketing, Journal of Internet Commerce, 6(1), 83-99.

İslamoğlu, A.H. (1999). Pazarlama Yönetimi. İstanbul: Beta Basım Dağıtım.

Kara, A. \& Kaynak, E. (1997). Markets of a Single Customer: Exploiting Conceptual Developments in Market Segmentation, European Journal of Marketing, 31(11/12), 873-895.

Kotler P. (2003). Marketing Management, Prentice Hall, New Jersey.

Kozak, A.M. \& Bahçe, S. (2009). Özel İlgi Turizmi, Ankara: Detay Yayıncılık.

Küçükaslan, N. (2009) "Özel İlgi Turizminde Niş Pazarlamanın Yeri", Paradoks, Ekonomi,Sosyoloji ve Politika Dergisi, 2(2), (e-dergi), http://www.paradoks.org. (Erişim Tarihi:10.10.2016).

Linneman, R. E., \& Stanton, J. L. (1991). Making Niche Marketing Work: How To Grow Bigger by Acting Smaller. New York: McGraw-Hill, Inc.

Noy, E. (2010). Niche strategy: merging economic and marketing theories with population ecology arguments. Journal of Strategic Marketing. 18(1), 77-86.

Novelli, M. (2005). Niche tourism: Contemporary issues, trends and cases. Burlington, MA: Elsevier Butterworth-Heinemann.

Odabaşı, Yavuz. (2012). Postmodern Pazarlama. 3.Baskı, İstanbul: MediaCat Yayınları. 


\section{Journal of Business Management and Economic Research}

Özcan, M. (1997). Niche Marketing (Niş Pazarlama) ve Kobiler. Pazarlama Dünyası. 11(62), 2021.

Öztürk, Y. \& Yazıcıoğlu, İ. (2002). Gelişmekte olan ülkeler için alternatif turizm faaliyetleri üzerine teorik bir çalışma. Gazi Üniversitesi Ticaret ve Turizm Eğitim Fakültesi Dergisi, 2, 183195.

Parrih, E.D. (2003). Niche Market Opportunities in The Global Marketplace, Doktora Tezi, North Carolina State University, Amerika.

Parrish, E.D., Allen, R., Cassil, N.L., Oxenham W., \& Jones M.R. (2005). The use of a niche market strategy by US textile and apparel firms. Journal of The Textile Institute, 96(2), 77-85.

Shani, D., \& Chalasani, S. (1992). Exploiting Niches Using Relatin Marketing. The Journal of Services Marketing. 6(4), 43-52.

Soyuer, H. \& Ventura, K. (2004). Bütünleşik Bilgi Sistemi Uygulamaları ve Üretim Pazarlama Arayüzü, 3. Ulusal Bilgi, Ekonomi ve Yönetim Kongresi Bildiriler, Eskişehir, 25 -26.

Tekeli, H. (2001). Turizm Pazarlaması ve Planlaması, Ankara: Detay Yayınc1lı.

Yapraklı, Ş. (2004). Niş Pazarlama ve Tüketici Tatmini Üzerindeki Etkisi. Doktora Tezi, Atatürk Üniversitesi Sosyal Bilimler Enstitüsü İşletme Anabilim Dalı.

Weinstein, A., (1994). Market Segmentation: using Demographics, Psychographics, and other Niche Marketing Techniques to Predict and Model Customer Behavior, Probus Publishing Co., Chicago, IL. 